\title{
Improving Teacher Performance through Transformational Leadership Development, Pedagogic Competency, and Achievement Motivation
}

\author{
Daningsih Kurniasari*, Soewarto Hardhienata, Bibin Rubini \\ Pakuan University, Bogor, Indonesia
}

*Corresponding Author: Daningsih Kurniasari, Pakuan University, Bogor, Indonesia

\begin{abstract}
Improving teacher performance is a critical requirement in improving the quality of education and producing superior quality graduates. Improving teacher performance can be done in various ways, among others, through the application of school-based management (school base management) to facilitate the Principal in updating teacher training and supervision creatively, planned, directed, and continuously, to encourage the achievement of increasing teacher performance. This study aims to determine the effect of transformational leadership, pedagogical competence, and achievement motivation on improving teacher performance in Private Junior High Schools in the City of Depok. This research is a study Sequential Explanatory using a combination of research methods (mixed method)) begins with the quantitative research phase and is followed by qualitative research. The results showed that transformational leadership had an effect on teacher performance $52.3 \%$, pedagogical competence affected teacher performance $30.3 \%$, and achievement motivation had an impact $51.3 \%$ on teacher performance. These three variables, if combined, will have as much influence $59.1 \%$ on teacher performance. Further, SITOREM (Scientific Identification Theory for Operational Research in Education) is performed to determine the area of improvement for the respective schools.
\end{abstract}

Keywords: Teacher performance, transformational leadership, pedagogical competence, achievement motivation

\section{INTRODUCTION}

Education is a strategic and useful tool in developing the potential of students to become human beings who have faith and are devoted to God Almighty, noble, healthy, knowledgeable, capable, creative, independent, and become democratic and responsible citizens, as stated in the Law of the Republic of Indonesia Number 20 of 2003 concerning the National Education System. Education also aims to improve the quality of Indonesian human resources through heart processing, taste, and sports, to produce people who are knowledgeable, characterized and cultured, so that they are highly competitive to face global challenges. Therefore, education must continue to be improved to be able to achieve goals effectively and efficiently (Futrell, 2010).

According to Taylor (2012), improving teacher performance must continue to be done at each level of education to improve the quality of education graduates to become quality human resources. It is believed that quality human resources are the most decisive factor in spurring growth in various fields of development. The availability of quality human resources will encourage the Indonesian people to be able to achieve excellence in producing quality works and be able to compete with other nations at the global level. However, the reality on the ground is that teacher performance has not yet shown the achievements as expected and still needs improvement and improvement.

Based on a preliminary study of A-accredited private junior high school teachers in the Depok City area, obtained some information obtained from the results of teacher performance assessments (PKG) by the School Principal in academic supervision and school supervisors, namely that private Junior High School teachers are accredited A in the region The city of Depok is mostly underperforming with a range of values between 61-75 (adequate category), whereas based on the Regulation of the Minister of Administrative Reform and Bureaucracy No. 16 of 2009 which classifies performance values namely 91-100 in excellent categories (performance above standard), 76-90 categories in good 
(performance according to standards), 61-75 categories enough (performance under standard) 51-60 moderate categories (performance not accepted).

Based on the phenomena that occur relating to problems of teacher performance and corroborated with data from school principals and school supervisors, it is necessary to research teacher performance and factors related to it. From the description above, we get the problem formulation:

- Is there a relationship between principals' transformational leadership and teacher performance?

- Is there a relationship between pedagogical competence and teacher performance?

- Is there a relationship between achievement motivation and teacher performance?

- Is there a relationship between the principal's transformational leadership, pedagogical competence, and achievement motivation together with teacher performance?

\section{BASIC THEORY}

\subsection{Teacher Performance}

Ballou (2015), suggest that teacher performance is the ability and effort of teachers to carry out learning tasks as well as possible, starting from 1. planning learning programs, 2. implementing learning activities, and 3. evaluating learning outcomes. A good teacher's performance is the teacher's performance, which results in the achievement of learning objectives according to the standards set by the school. Millanowski (2011), argues that a teacher can be said to have poor performance if the achievement is not satisfactory, because it is below the standard criteria that have been set. This means that the teacher has failed in carrying out their duties and responsibilities. Teacher performance is the teacher's effort in realizing his abilities in the form of attitudes, knowledge, and skills in 1. planning, 2. implementing, 3. evaluating learning, and 4. following up on learning evaluation results effectively and efficiently to achieve maximum learning outcomes.

\subsection{Transformational Leadership}

Gumusluoglu (2009) said that transformational leaders change the personal values of subordinates to support the vision and goals of the organization by fostering an environment where relationships can be formed by building a climate of trust, organizational vision can be adequately conveyed. Indicators of transformational leadership are 1. subordinates feel trust, admiration, loyalty, and respect for their leaders. 2. subordinates are motivated to do more than expected, 3. make improvements and changes in the organization. Harms (2010), states that transformational leadership is a relationship of mutual encouragement and mutual respect that transforms followers into leaders and can convert leaders into moral agents", thus resulting in a transformation effect on both leaders and followers. Transformational leadership consists of four indicators, namely: 1. charisma or ideal influence, 2. inspirational leadership or motivation, 3. intellectual stimulation, and 4. individual consideration.

\subsection{Teacher Pedagogical Competencies}

According to Carril (2013), pedagogic competence is the ability of teachers in understanding students, designing and implementing learning, evaluating learning outcomes, and developing students to actualize their various potentials. In more detail, it is translated into several essential indicators, namely: 1. understanding students; understanding students by utilizing the principles of cognitive development, personality principles, and identifying students' initial learning provisions, 2 . designing learning; understand the educational foundation, apply knowledge and learning theories, determine learning strategies based on the characteristics of students, the competencies to be achieved and develop learning plans based on the chosen strategy, 3. implementing learning; organize the setting of knowledge, and carry out conducive learning, 4. design and carry out evaluation; design and achieve an evaluation of the process and learning outcomes on an ongoing basis with various methods, analyze the results of the assessment of the process and learning issues to determine the level of mastery learning, utilize the results of learning assessments to improve learning programs in general, and 5. develop students; developing various academic potentials and facilitating students to develop multiple non-academic possibilities. 


\subsection{Achievement Motivation}

According to Buttler (2012), achievement motivation is the encouragement of a person to complete challenging work, succeed in a competition and show a desire to get clear feedback on performance, characteristics, and attitudes of achievement-motivation in question, among others: 1 . achievement is more important than material, 2. achieving a goal or task provides greater personal satisfaction than receiving praise or acknowledgment, and 3. feedback is essential, because it is a measure of success (reliable, quantitative and factual feedback). Suswanto (2017), argues that achievement motivation is achieving something difficult to master, anticipating ways of working or organizing ideas to achieve physical goals, doing work quickly, and trying to exceed or rival the achievements of others. The indicators are 1. choosing a job with a moderate level of difficulty, 2. accepting a situation that allows its performance to succeed on the encouragement of other factors, 3. wanting more feedback about the successes and failures of its achievements.

Based on the mindset as stated above, the following hypotheses are proposed:

- There is a positive relationship between the principal's transformational leadership style and teacher performance.

- There is a positive relationship between pedagogical competence and teacher performance.

- There is a positive relationship between achievement motivation and teacher performance.

- There is a positive relationship between the principal's transformational leadership style, pedagogical competence, and achievement motivation, together with teacher performance.

\section{Method}

This research was conducted to teachers of the Public-Private and Private Islamic Middle Schools accredited "A" in the City of Depok, West Java, from July 2017 to April 2019. This research is a study Sequential Explanatory using a combination of research methods (mixed method)) begins with the quantitative research phase and is followed by qualitative research. The technique used at this stage is a survey method with a correlational approach. Empirical data collected consisted of three independent variables, namely transformational leadership $\left(X_{1}\right)$, teacher pedagogical competence $\left(\mathrm{X}_{2}\right)$, and teacher achievement motivation $\left(\mathrm{X}_{3}\right)$, with the dependent variable, namely teacher performance $(\mathrm{Y})$. The instrument used for data collection at this stage was a questionnaire, a Likert scale compiled based on the indicators in the research variables. Primary data examined are data about transformational leadership, pedagogical competence, achievement motivation, and teacher performance. To see how much the strength of the relationship between the independent variable and the dependent variable and to get the optimal solution from this study can be seen in the picture of the research and statistical constellation based on the Theory of Scientific Introduction to Operations Research in the field of Educational Management

\section{RESULTS AND DISCUSSION}

\subsection{The Relationship between Principals' Transformational Leadership and Teacher Performance}

The results of research and hypothesis testing show that there is a positive and significant relationship between the principal's transformational leadership and teacher performance, which is indicated by the simple correlation coefficient $\left(\mathrm{r}_{\mathrm{y} 1}\right)$ is 0.523 (moderate correlation) and the coefficient of determination $\left(\mathrm{r}^{2}\right)=0.273$, which means that Principal transformational leadership contributed to teacher performance by $27.3 \%$, and the remaining $72.7 \%$ was determined by other factors while simple regression equation $\mathrm{y}=71.788+0,510 \mathrm{X}_{1}$, which means that each increase of one unit of transformational leadership score principals will give a tendency to increase teacher performance score of 0.510 at 71.788 constants.

The results of qualitative research through observations, interviews, FGDs, and documentation studies on "A" accredited private and public, private Islamic junior high schools in Depok, West Java, reveal that there is a positive relationship between the principal's transformational leadership and teacher performance, which reinforces the results of research on quantitative stage. The two phases of the study concluded that the higher the principal's transformational leadership, the higher the teacher's performance or vice versa. 
D'Agostino (2009), also explains that in transformational leadership, there is a dimension inspirational motivation, which describes leaders who can communicate high expectations, use symbols to focus hard work, express essential goals in a simple way. The results of this study also provide recommendations for the importance of principals to apply transformational leadership to teachers in carrying out school management by presenting an interesting vision of the future, challenging teachers with high standards, speaking optimistically with enthusiasm and encouraging meaningful about what is needed to be done by the teachers.

The results of this study are in harmony and reinforce the results of research conducted by Eguarino (2017), the conclusion results include "there is a positive and significant influence on the principal transformational leadership style on teacher teaching performance with a correlation coefficient ry ${ }_{1}=$ 0.789 (strong correlation), it means that the better the transformational leadership of the principal, the better the teacher's teaching performance. This means that principals need to work hard to implement their transformational leadership in fostering teachers so that they contribute significantly to teacher performance.

Based on the results of this study, it can be seen that the variables of transformational leadership and achievement motivation on teacher performance have a stronger connection value than the pedagogical competency variable. The results of this study also found that there are indicators that need to be developed from each independent variable, as follows: a. Intellectual stimulation, b. Like a challenge, c. Able to plan KBM, d. Able to follow up, e. assessment and evaluation, f. potential development of students, g. Mastering learning theory \& learning principles, h. Curriculum development, i. Educational learning, j. Communication with students (Loneey, 2011).

\subsection{The Relationship between Pedagogical Competence and Teacher Performance}

Quantitative research results show there is a positive and significant relationship between pedagogical competence with teacher performance, with the correlation coefficient $\mathrm{r}_{\mathrm{y} 2}=0.303$ (weak correlation) and the coefficient of determination $\mathrm{R} 2=0.092$ means pedagogical ability contributes to teacher performance by $9.2 \%$ and the remaining $90.8 \%$ is determined by other factors. Medium regression equation showed $\mathrm{Y}=25.430+0,748 \mathrm{X}_{2}$ means that each increase of one unit score pedagogical competence would contribute to the improvement of teacher performance score of 0.748 at 25.430 constants.

The results of qualitative research through observations, interviews, FGDs, and documentation studies on "A" accredited private and public, private Islamic junior high schools in Depok, West Java, reveal that there is a positive relationship between pedagogical competence and teacher performance, which means strengthening the results of research at the quantitative stage. The two stages of the study concluded that the higher the pedagogical competence, the higher the teacher's performance or vice versa.

The results of the study above, indicate the existence of reinforcement or support for the pedagogical competence theory as stated by Hakim (2015) explains that pedagogic competence, in general, describes the skills and self-management related to supervision in learning to achieve the expected teacher performance. The results of the above study are also in line with the theory of pedagogical competence, as stated by Chai (2010) which states: Pedagogical competence can be described as the ability and willingness to apply regular attitudes, knowledge, and learning skills of teachers in managing students. This is consistent with the objectives indicated in the teacher's framework, which is carried out continuously to develop its competencies.

In addition to being in line with or reinforcing the theory of pedagogical competence as outlined above, the results of the research mentioned above, also support the results of research conducted by Hakim (2015) which concluded that pedagogical influence on teacher performance correlation coefficient $\mathrm{r}_{\mathrm{y} 2}=0.119$ (weak correlation) and the coefficient of determination $\mathrm{R}^{2}=0.014$, which means that pedagogical contributes to the performance of teachers by 1.4 The remaining\% is $98.6 \%$ determined by other factors.

Based on these findings, it can be stated that the improvement in teacher performance can be improved through the development of pedagogical competencies, particularly the mastery of learning theories and learning principles, curriculum development, and the development of potential learners. 


\subsection{The Relationship between Achievement Motivation and Teacher Performance}

Quantitative research results indicate that there is a positive and significant relationship between achievement motivation and teacher performance, with the correlation coefficient ry. $3=0.510$ (moderate correlation) and the coefficient of determination $\mathrm{R} 2=0.260$ means Achievement motivation contributes to teacher performance by $26 \%$ and the remaining $74 \%$ is determined by other factors. Average regression coefficients indicate $\mathrm{Y}=59.071+0,596 \mathrm{X}_{3}$ means that each increase of one unit of achievement motivation scores will contribute to the improvement of teacher performance score of 0.596 at 59.071 constants.

The results of qualitative research through observations, interviews, FGDs, and documentation studies on accredited A private and private Junior High School in Depok, West Java, revealed that there was a positive relationship between achievement motivation and teacher performance, which ran to strengthen the results of the research at the quantitative stage. The two stages of the study concluded that the higher the achievement motivation, the higher the teacher's performance or vice versa.

The results of this study, in line with Chi (2012) which says that achievement is the ability to carry out difficult tasks and jobs, manipulate or organize fiscal objects, the ability to express ideas to carry out tasks and work as quickly as possible and independent may be in accordance with prevailing conditions, achieve peak performance for yourself, be able to win the competition with other parties and succeed in improving themselves through the application of talent.

The conclusion of this study supports the theory of performance as proposed McCleskey (2014) suggests the mental attitude factor, which includes achievement motivation, work discipline, and work ethics can affect one's performance. Teachers who have a good mental attitude will work with full sincerity and high motivation. Every person who works with high motivation, then his work discipline will be good. High work motivation is supported by good work discipline and implemented with polite work ethics will certainly produce high performance.

\subsection{Relationship between the Principal's Transformational Leadership, Pedagogical Competence, and Achievement Motivation Together with Teacher Performance}

The results of research and hypothesis testing indicate that there is a positive and significant relationship between the principal's transformational leadership, pedagogical competence, and achievement motivation together with teacher performance, which is indicated by multiple correlation coefficient $\left(\mathrm{R}_{\mathrm{Y} 123}\right.$ ) is 0.591 (correlation medium) and the coefficient of determination $\left(\mathrm{R}^{2)}=0.349\right.$, which means that transformational leadership principals, pedagogical competence and achievement motivation jointly contribute to the performance of teachers at $34.9 \%$, and the remaining $65.1 \%$ are determined by other factors. While the simple regression equation $\hat{Y}=42,251+0,318 \mathrm{X}_{1}+0,373 \mathrm{X}_{2}+$ $0,282 \mathrm{X}_{3}$, which means that each increase in one unit of the principal's transformational leadership score, pedagogical competence, and achievement motivation together will provide a tendency towards increasing teacher performance scores amounted to 0.973 on the constant 42.251 . Thus, it can be concluded that the higher the principal's transformational leadership, pedagogical competence, and achievement motivation together, the higher the teacher's performance or vice versa. In other words, the principal's transformational leadership, pedagogical competence, and achievement motivation can jointly improve teacher performance.

The results of qualitative research through observations, interviews, FGDs, and documentary studies on public-private and Islamic private schools accredited "A" in the City of Depok, West Java, it is known that the principal has built teacher morality by instilling trust, admiration, loyalty, and respect for leaders, and teachers are motivated to do more than they initially expected.

The school principal has optimally transformed the teachers about the school's resources to achieve meaningful goals following predetermined achievement targets. The school principal has also encouraged teachers to carry out their duties with quality above previous assignments or above the achievements of teachers in other schools.

The principal has instilled a commitment to the teacher to be able to create a synergy in the school, optimize, motivate and teachers to be able to carry out their tasks or work, including work that is genuinely challenging and provides opportunities for teachers to work more creatively capable of 
solving problems, so that it has provided added value for improving teacher performance in learning at school.

The qualitative research findings above show a positive relationship between the principal's transformational leadership, pedagogical competence, and achievement motivation, together with teacher performance, which means strengthening the results of the research at the quantitative stage.

Qualitative research results also indicate support that the variable that most influences teacher performance is the transformational leadership variable, and the least influential variable is the pedagogical competency variable. This is because the principal transformational leadership factor in private schools is more dominant in providing direction, stimulation, and example to teachers. This means that the better the principal's leadership, the better the teacher's performance.

The results of qualitative data reduction indicate that other variables that are assumed to be related to teacher performance are organizational culture, transactional leadership, personality competencies, social competencies, entrepreneurial competencies, principal supervision, teacher welfare, interpersonal communication, and teacher work experienrevece. The SITOREM (Hardienata, 2017) analysis revealed below:

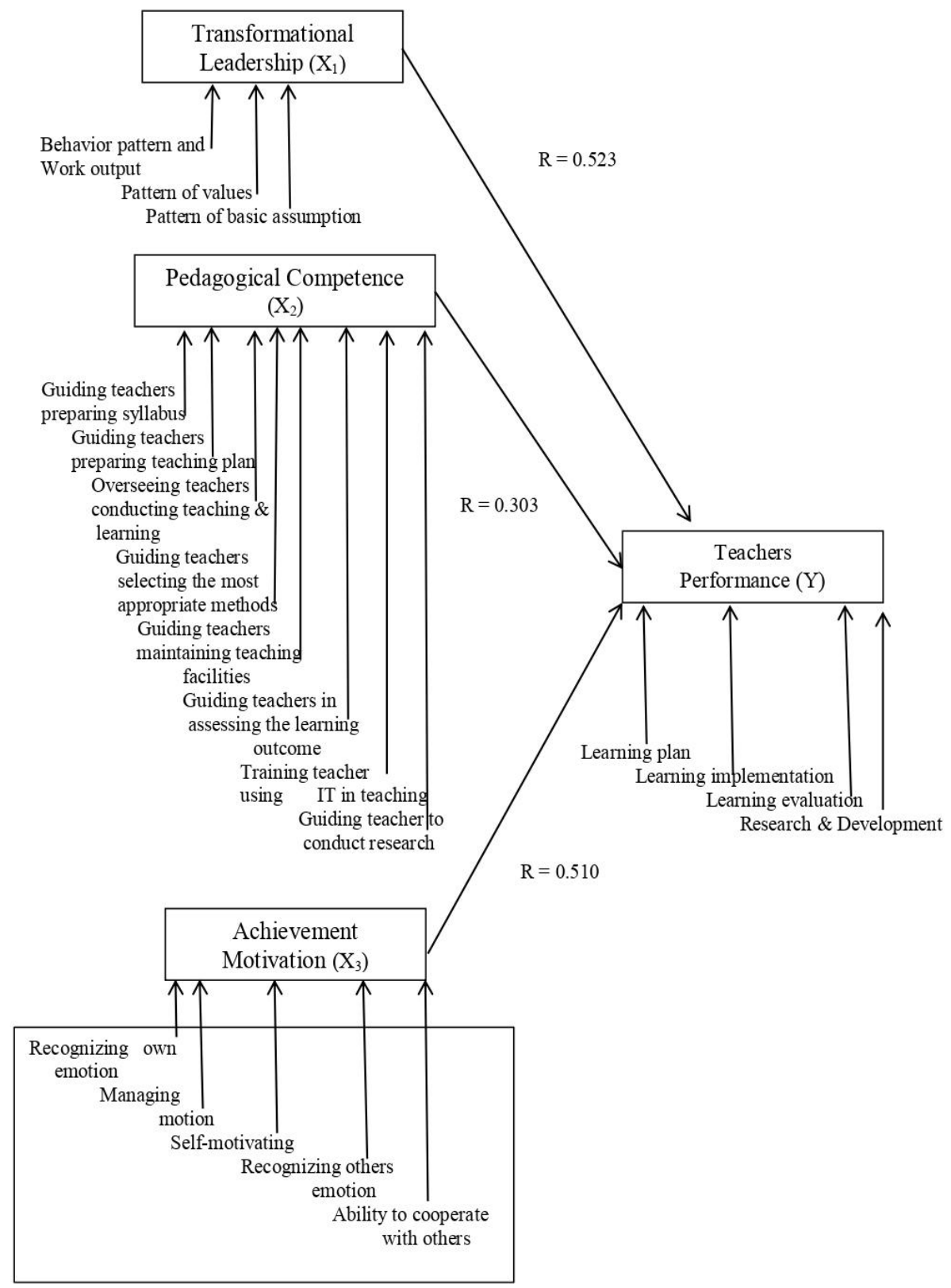

Figure1: Analysis of SITOREM (Scientific Identification Theory for Operational Research in Education) 
Based on the above, as a follow up(ActionPlan) of this study made an action plan or is an activity that aims to design programs that can be an alternative to efforts to improve matters related to improving the application of emotional intelligence indicators to permanent teachers of foundations and managers of Public-Private and Private Islamic Middle Schools accredited "A" in the City of Depok, West Java in order to increase commitment to the Organization in schools so that educational goals can be achieved more efficiently.

\section{CONCLUSION}

Based on the results of the analysis of research data, it can be concluded that this study has found efforts for the performance of A accredited private junior high school teachers in Depok City, by identifying the strength of the relationship between the research variables, as follows:

- There is a positive and significant relationship between principals' transformational leadership and teacher performance $\left(\mathrm{r}_{\mathrm{y} 1}=0.523, \rho<0.01\right)$ with the strength of a moderate relationship. This relationship was strengthened by the results of qualitative research, which revealed that the principal's transformational leadership could contribute to improving teacher performance. Based on these findings, efforts to improve teacher performance can be made through the development of the principal's transformational leadership.

- There is a positive and significant relationship between pedagogical competence and teacher performance $\left(r_{y 2}=0.303, \rho<0.01\right)$ and the strength of the weak relationship. This relationship is strengthened by the results of qualitative research, which revealed that pedagogical competence could contribute to improving teacher performance. Based on these findings, efforts to improve teacher performance can be made by developing pedagogical competencies.

- There is a positive and significant relationship between achievement motivation and teacher performance, which is indicated by the simple correlation coefficient $\left(\mathrm{ry}_{3}=0.510\right)$ and the strength of the moderate relationship. The relationship is strengthened by the results of qualitative research, which revealed that achievement motivation could contribute to improving teacher performance. That is, every increase in achievement motivation is followed by an increase in teacher performance; in other words, achievement motivation can predict the high and low performance of teachers.

- There is a positive and significant relationship between the principal's transformational leadership, pedagogical competence, and achievement motivation, together with teacher performance $\left(r_{\mathrm{y} 123}=\right.$ 0.591). This relationship was strengthened by the results of qualitative research, which revealed that the principal's transformational leadership, pedagogical competence, and achievement motivation together could contribute to improving teacher performance. Thus, each increase in the principal's transformational leadership, pedagogical competence, and achievement motivation together will be followed by an increase in teacher performance. In other words, the principal's transformational leadership, pedagogical competence, and achievement motivation together can predict the high and low performance of teachers.

\section{REFERENCES}

[1] Ballou D, Springer MG. Using student test scores to measure teacher performance: Some problems in the design and implementation of evaluation systems. Educational Researcher. 2015 Mar; 44(2):77-86.

[2] Butler R. Striving to connect: Extending an achievement goal approach to teacher motivation to include relational goals for teaching. Journal of Educational Psychology. 2012 Aug; 104(3):726.

[3] Carril PC, Sanmamed MG, Sellés NH. Pedagogical roles and competencies of university teachers practicing in the e-learning environment. The International Review of Research in Open and Distributed Learning. 2013 Jul 5; 14(3):462-87.

[4] Chai CS. The relationships among Singaporean preservice teachers' ICT competencies, pedagogical beliefs and their beliefs on the espoused use of ICT. The Asia-Pacific Education Researcher. 2010; 19(3):387-400.

[5] Chi HK, Lan CH, Dorjgotov B. The moderating effect of transformational leadership on knowledge management and organizational effectiveness. Social Behavior and Personality: an international journal. 2012 Jul 1; 40(6):1015-23.

[6] D’Agostino JV, Powers SJ. Predicting teacher performance with test scores and grade point average: A meta-analysis. American Educational Research Journal. 2009 Mar; 46(1):146-82. 
[7] Gumusluoglu L, Ilsev A. Transformational leadership, creativity, and organizational innovation. Journal of business research. 2009 Apr 1; 62(4):461-73.

[8] Hardhienata, S. (2017, January). The development of scientific identification theory to conduct operation research in education management. In IOP Conference Series: Materials Science and Engineering (Vol. 166, No. 1, p. 012007). IOP Publishing.

[9] Hakim A. Contribution of competence teacher (pedagogical, personality, professional competence and social) on the performance of learning. The International Journal of Engineering And Science (IJES). 2015; 4(2):1-2.

[10] Harms PD, Credé M. Emotional intelligence and transformational and transactional leadership: A metaanalysis. Journal of Leadership \& Organizational Studies. 2010 Feb; 17(1):5-17.

[11] Futrell MH. Transforming teacher education to reform America's P-20 education system. Journal of Teacher Education. 2010 Nov; 61(5):432-40.

[12] Guarino CM, Maxfield M, Reckase MD, Thompson PN, Wooldridge JM. An evaluation of empirical Bayes's estimation of value-added teacher performance measures. Journal of Educational and Behavioral Statistics. 2015 Apr; 40(2):190-222.

[13] Looney J. Developing High-Quality Teachers: teacher evaluation for improvement. European Journal of Education. 2011 Dec; 46(4):440-55.

[14] McCleskey JA. Situational, transformational, and transactional leadership and leadership development. Journal of Business Studies Quarterly. 2014 Jun 1; 5(4):117.

[15] Milanowski A. Strategic measures of teacher performance. Phi Delta Kappan. 2011 Apr; 92(7):19-25.

[16] Suswanto H, Asfani K, Prasetya AW. Contribution of teaching performance, learning satisfaction and achievement motivation to students' competence achievement. Glob. J. Eng. Educ.. 2017; 19.

[17] Taylor ES, Tyler JH. The effect of evaluation on teacher performance. American Economic Review. 2012 Dec; 102(7):3628-51.

Citation: Daningsih Kurniasari, et.al. "Improving Teacher Performance through Transformational Leadership Development, Pedagogic Competency, and Achievement Motivation" International Journal of Managerial Studies and Research (IJMSR), vol 7, no. 12, 2019, pp. 1-8. doi: http://dx.doi.org/10.20431/23490349.0712001.

Copyright: (C) 2019 Authors. This is an open-access article distributed under the terms of the Creative Commons Attribution License, which permits unrestricted use, distribution, and reproduction in any medium, provided the original author and source are credited. 